\title{
Distribution and molecular identification of Meloidogyne spp. associated with tomato (Lycopersicon esculentum) cultivation in the Agro-ecological zone of the Guinean high savannah of Cameroon (Adamawa)
}

\author{
Blaise Kamaya ${ }^{1,}{ }^{*}$, Jacqueline Vildina Dikti ${ }^{2}$, Toua Vroumsia ${ }^{1}$ and Dieudonne Ndjonka ${ }^{1}$ \\ ${ }^{1}$ Department of Biological Sciences, University of Ngaoundere, P. O. Box 454 Ngaoundere, Cameroon. \\ ${ }^{2}$ Department of Biomedical Sciences, University of Ngaoundere, P. O. Box 454 Ngaoundere, Cameroon.
}

GSC Biological and Pharmaceutical Sciences, 2022, 18(02), 268-282

Publication history: Received on 13 January 2022; revised on 19 February 2022; accepted on 21 February 2022

Article DOI: https://doi.org/10.30574/gscbps.2022.18.2.0076

\begin{abstract}
Meloidogyne represent a genus of plant-parasitic nematode. This nematode is serious crop pests, including tomatoes and is widespread in almost all regions of the world. Very little attention has been paid to these parasites in Cameroon and none in the agro-ecological zone of the Guinean high savannah. We therefore undertook this study to identify and assess the density of this nematode in this area. For this study, a total of 30 root samples were collected in tomatoes production areas from 4 districts and females Meloidogyne were isolated and counted. Specific identification was done by Polymerase Chain Reaction (PCR) using the markers C2F3/1108 and COX1. The genus Meloidogyne was thus identified in the 30 production basin sites of this zone. High densities of Meloidogyne were observed in 18 sites, with an average density of between 21-50 females per gram of fresh root. In contrast, low densities were noted at 12 sites with values between 6 and 19 females per gram of root. However, this distribution is function of the cropping period, soil texture, $\mathrm{pH}$, organic matter content, soil saturation rate, and cropping practices (host or non-host plants and fallow practice). Electrophoretic profiles of Deoxyribonucleic Acid (DNA) amplified with C2F3/1108 and COX1 primers showed corresponding migrations at $1700 \mathrm{bp}, 1100 \mathrm{bp}$ and $421 \mathrm{bp}$ characteristic of the presence of $M$. incognita/M. javanica, M. arenaria and $M$. incognita/M. hapla in this agro-ecological zone. In view of these results, which provide information on the distribution of Meloidogyne in this area, it seems necessary for producers to develop management strategies by improving preventive techniques and by piloting technical and cultural itineraries for the control of this plant pest.
\end{abstract}

Keywords: Meloidogyne; Lycopersicon esculentum; DNA; C2F3/1108; COX1; Agro-ecological zone

\section{Introduction}

The genus Meloidogyne, commonly known as root-knot nematodes, are a genus of obligate plant-parasitic nematodes. These nematodes are the most serious enemies of crops in all latitudes. They parasitize more than 5500 plant species [1] and are widespread in almost all regions of the world. They are often found in tropical and subtropical regions, temperate regions, and even in greenhouses setup. It has been found in southern USA, Australia, West Africa (Nigeria, Ghana, Ivory Coast, Senegal), Cameroon [2]. These parasites are compromising food security worldwide, accentuated by climate change in recent decades [3]. Infection by these root-knot nematodes results in losses estimated at US\$78 billion worldwide each year [4]. Attacks by these soil-borne pests often go unnoticed, causing damage that can in some cases reach $100 \%$ of the crop. In the USA, they amount to 266 million dollars per year [5]. In Senegal, the importance of losses due to the Me1oidogyne genus no longer needs to be demonstrated: a nematicide treatment on tomatoes allowed a $25 \%$ increase in yield [6]. To remedy this parasitic pressure and increase the resilience of the population in the face

\footnotetext{
${ }^{*}$ Corresponding author: Blaise Kamaya

Department of Biological Sciences, University of Ngaoundere, P. O. Box 454 Ngaoundere, Cameroon.
} 
of food insecurity, agricultural policy now gives pride of place to irrigated crops, particularly market gardening, which is receiving special attention. However, tomatoes production in this sector is the subject of growing interest in Cameroon.

From the Solanaceae family, the tomato (Lycopersicon esculentum) is an annual herbaceous plant, widely cultivated for its fruit [7]. It is a relatively short-cycle vegetable plant, grown in open field or under cover for a short or long production period. It is considered one of the most important vegetables in the human diet. According to the Food and Agriculture Organization of the United Nations (FAO), tomatoes are the second most important vegetable crop after potatoes. It occupies a world surface area of more than 4,626,232 ha with an estimated production of 126 million tonnes in 2008 [8]. In Cameroon, urban and peri-urban agriculture has been growing since the advent of the economic crisis. Tomatoes are grown throughout the country and are among the most produced and consumed vegetables [9]. Its production amounts to 572,219 tonnes [10]. The average yield is estimated at $4 \mathrm{t} / \mathrm{ha}$. Tomatoes cultivation has become a significant source of income for many households, capable of generating on small areas (in absence of pests) of land an income higher than the minimum monthly salary of some civil servants and in a relatively short period of time [11]. The cultivation of tomatoes is now a viable economic activity for many rural, urban and peri-urban producers. Tomatoes cultivation is a source of employment. However, despite the measures taken and techniques used, tomato cultivation in certain areas faces many difficulties. Indeed, one of the constraints to this production could be linked to the parasitic pressure, particularly the Meloidogyne genus, considered a formidable enemy of this crop [12]. Losses due to nematodes vary by nematode species and between geographical regions. However, in Cameroon, there are five agro-ecological zones where tomatoes cultivation is becoming more and more important. In the interest of agronomic, environmental and economic improvement of production and to achieve food security objectives, agricultural policy must be oriented towards a diversification of alternative methods of Meloidogyne control based firstly on the respect of human health and the environment, but they must also be effective and sustainable. The success of any pest control depends on a good diagnosis. However, very little interest has been shown in plant-parasitic nematodes in Cameroon in general and no study has been carried out on the genus Meloidogyne in the Cameroonian high savannah zone in particular. It is in this context that we undertook this study whose objective was to study and identify the various species of Meloidogyne found in Cameroon high savannah zone in order to contribute to the control of this plant-parasitic nematode.

\section{Material and methods}

\subsection{Study area}

The study area chosen for this work is the high Guinean savannah (Cameroon). The choice of this area is due to ecological reasons. It offers a variety of vegetable growing systems. It lies between $5^{\circ} 42^{\prime \prime}$ and $8^{\circ} 36^{\prime \prime}$ North latitude, $11^{\circ} 24^{\prime \prime}$ and $14^{\circ} 36^{\prime \prime}$ East longitude. It mainly covers Adamawa region as well as a northern part, departments of Mbam (Central region) and Lom-et-Djerem (Eastern region). It over a total area of $138000 \mathrm{~km}^{2}$ [13]. This area is made up of a vast plateau at an altitude of between 900 to $1500 \mathrm{~m}$, with peaks reaching $1800 \mathrm{~m}$ [13]. The climate is of the Sudanese type, tropical humid with two seasons per year [14]. The rainy season runs from April to October with an average rainfall of $1.675 \mathrm{~mm}$ /year with about 150 days of rainfall per year (Source: MINADER Regional Delegation of Adamawa, 2014). Following a survey visit in 2018, four districts were selected for sampling in April and May, then in September and October (periods of intense market gardening activity) of the same year. These were the district of Ngaoundere I Ngaoundere II , Ngaoundere III e and Nganha, corresponding to the tomatoes production basins in this agro-ecological zone (figure 1). The average monthly isotherms (temperature), the average monthly isohyets (rainfall) as well as the maximum and minimum humidity of the sampling periods were taken from data collected over the year 2018 in the meteorological station of the Agency for the Safety of Aerial Navigation in Africa and Madagascar (ASECNA) in Ngaoundere.

\subsection{Sampling}

After observing the symptoms of possible root-knot nematode infestation at each selected survey site (presence of rootknots), 15 to 20 tomatoes roots were carefully removed with a chisel without removing the soil adhering to the roots. For each site, these roots samples were packed in separate plastic bags, labelled and put in a cooler, and placed in the shade to help preserve the roots. The cultivar, crop history, Global Positioning System (GPS) coordinates and sampling period of each site were noted. The samples collected were taken to the laboratory for analysis.

\subsection{Isolation of Meloidogyne females and counting}

The tomatoes roots once in the laboratory were separated from the soil, washed thoroughly to remove any remaining soil particles and then stored at $-20^{\circ} \mathrm{C}$ for 24 hours to help maintain the shape of the females when grinding the roots. 
After cool storage, the roots of each composite sample were cut with a chisel into approximately $1 \mathrm{~cm}$ fragments, mixed and three sub-samples of $50 \mathrm{~g}$ each were taken and placed in the blender bowl with just enough water to cover the blades. The roots were grind for 3-4 seconds, with a brief settling period between the three. The suspension of each ground root subsample was poured into a beaker and rinsed with a pail of water. White, swollen Meloidogyne females without eggs [15] were isolated and counted under a binocular magnifying lens (25x) and transferred to an eppendorf tube containing distilled water. The average of the three subsamples for each site was calculated and expressed as the number of females per gram of root. Finally, the importance of Meloidogyne was determined from the Frequency/Abundance diagram of Fortuner and Merny [16].

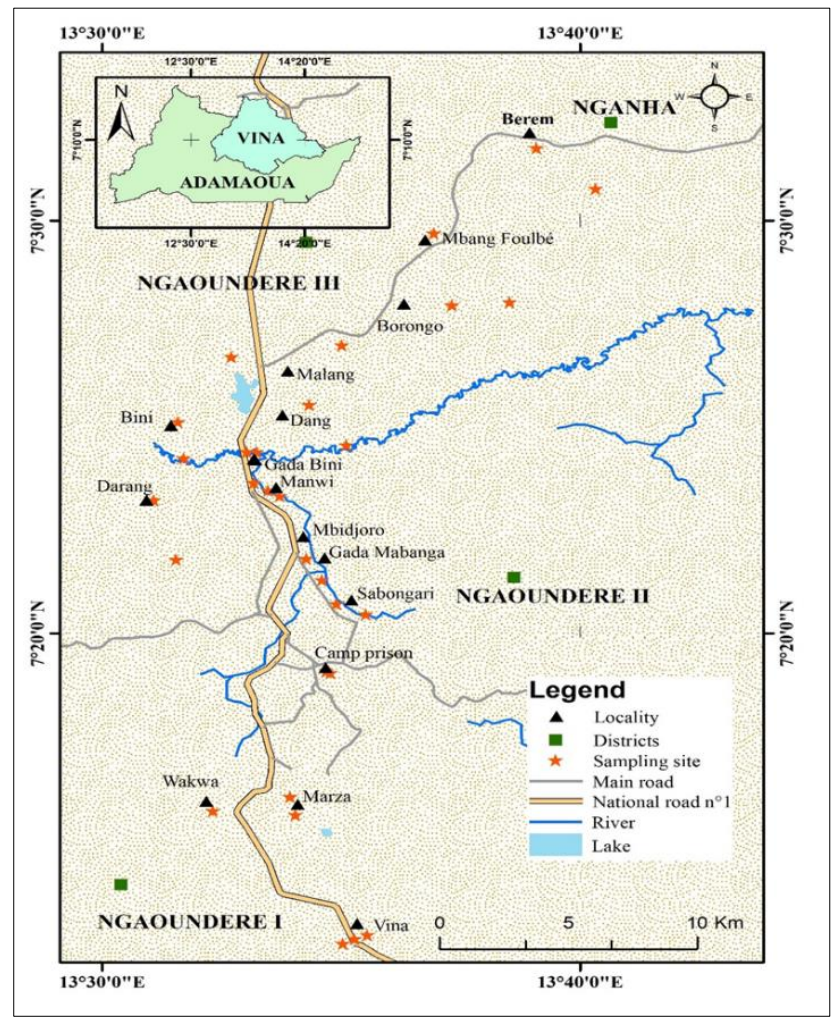

Figure 1 Map showing the different sampling area

\subsection{Physico-chemical soil analysis}

Samples of $250 \mathrm{~g}$ of soil surrounding the roots collected from the site were dried, sieved with a 2 mm mesh sieve, and then the physico-chemical properties of the soil were analyzed. These analyses concerned: the granulometry measured according to the Textol technique [17], nitrogen N [18] and organic carbon C [19] content by gas chromatography. Organic matter (OM) content is then calculated. The content of assimilable phosphorus by the Olsen method [20], the contents of soluble elements: calcium (Ca), magnesium (Mg), potassium (K), sodium (Na), iron (Fe) by fluoronitroperchloric dissolution [21], acidity $\left(\mathrm{pH}_{\mathrm{H} 2 \mathrm{O}}\right.$ ) [22] and cation exchange capacity (CEC) measured by conductivity [23].

\subsection{Molecular identification of Meloidogyne}

\subsubsection{DNA extraction}

Form each sample where females were isolated, 15-20 previously isolated females were crushed and transferred to a new tube and the DNA extracted using the QIAgen DN easy Blood \& Tissue Kit technique.

\subsubsection{PCR and DNA analysis by agarose gel electrophoresis}

Molecular characterization was carried out by amplification of the fragment of intergenic region between Cytochrome Oxidase II (COX2) and large subunit of ribosomal ribonucleic acid (rRNA) gene of the mitochondrial genome using the C2F3/1108 primer following the protocol of Powers and Harris [24] and by amplification of the mitochondrial DNA sequences of the Cytochrome Oxidase 1 (COX1) gene adapted from the work of Lazarova et al. [25] (table 1). The composition of the amplification mixtures is shown in Table 2 below and the PCR reaction was performed in a 
Thermocycler Prime. For the C2F3/1108 primers : after an initial denaturation step (5 minutes at $94^{\circ} \mathrm{C}$ ), the samples underwent 35 cycles, each with three temperature variation steps, including a denaturation step $\left(60\right.$ seconds at $\left.94^{\circ} \mathrm{C}\right)$, a hybridization step $\left(60\right.$ seconds at $\left.55^{\circ} \mathrm{C}\right)$, and an elongation step $\left(1\right.$ minute at $\left.72^{\circ} \mathrm{C}\right)$. At the end of the last cycle, a $7-$ minute incubation at $72^{\circ} \mathrm{C}$ completes the ongoing DNA syntheses. For COX1: after the first denaturation step (7 minutes at $94^{\circ} \mathrm{C}$ ), the samples also underwent 35 cycles comprising a denaturation step ( 60 seconds at $94^{\circ} \mathrm{C}$ ), a hybridization step $\left(60\right.$ seconds at $\left.52^{\circ} \mathrm{C}\right)$, and an elongation step $\left(1\right.$ minute at $\left.72^{\circ} \mathrm{C}\right)$. At the end of the last cycle, a 10 -minute incubation at $72^{\circ} \mathrm{C}$ completes the DNA syntheses.

The PCR amplification products were analyzed by agarose gel electrophoresis. A 1.5\% agarose gel was prepared in $1 \mathrm{x}$ TAE buffer (50 x TEA buffer: 1 mM Na2EDTA pH 8.0 and 40 mM Tris-Acetate pH 8.0) with $10 \mu$ l ethidium bromide (EB) added. Prior to being placed in the gel wells, $5 \mu$ of each amplified DNA sample was mixed with $2 \mu$ l of DNA loading solution (6X Loading Dye). Migration was performed in $1 \mathrm{x}$ TAE buffer under a potential difference of 100 volts at 140 $\mathrm{mA}$ for $35 \mathrm{~min}$. The amplified nucleic acid bands were then visualized under UV light, thanks to the fluorescence of the $\mathrm{BE}$ that intercalated between the nucleotide bases.

Table 1 Name, sequence and amplification size of different primers used for polymerase chain reaction of 30 Meloidogyne populations

\begin{tabular}{|c|c|c|c|c|}
\hline $\begin{array}{l}\text { Primers } \\
\text { names }\end{array}$ & Sequences of primers & $\begin{array}{l}\text { Fragments sizes } \\
\text { (bp) }\end{array}$ & $\begin{array}{l}\text { Species of } \\
\text { Meloidogyne }\end{array}$ & References \\
\hline \multirow{2}{*}{$\begin{array}{l}\text { C2F3 F } \\
1108 \mathrm{R}\end{array}$} & \multirow{2}{*}{ 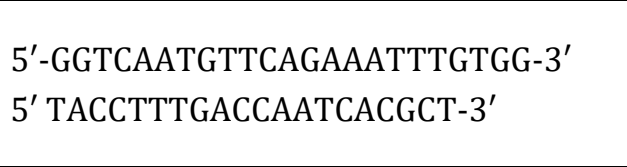 } & 1700 & $\begin{array}{l}\text { M. incognita / M. } \\
\text { javanica }\end{array}$ & \multirow[t]{2}{*}[24]{} \\
\hline & & 1100 & M. arenaria & \\
\hline $\begin{array}{l}\text { COX1 F } \\
\text { COX1 R }\end{array}$ & $\begin{array}{l}\text { 5'-TTGRTTTTTTGGTCATCCTGARG-3' } \\
\text { 5'-WSYMACWACATAATAAGTATCATG-3' }\end{array}$ & 421 & $\begin{array}{l}\text { M. incognita / } M \text {. } \\
\text { hapla }\end{array}$ & {$[25]$} \\
\hline
\end{tabular}

$\mathrm{F}=$ forward, $\mathrm{R}=$ reverse

Table 2 Composition of PCR reaction mixtures assembled for characterization of root-knot nematode populations

\begin{tabular}{|l|c|c|c|}
\hline \multirow{2}{*}{ Reagent } & \multirow{2}{*}{ Concentration } & \multicolumn{2}{|c|}{ Volume $(\boldsymbol{\mu l})$} \\
\cline { 3 - 4 } & & $\mathbf{C 2 F 3 / 1 1 0 8}$ & $\mathbf{C O X 1}$ \\
\hline Tampon (included $\left.\mathrm{MgCl}_{2}\right)$ & $20.0 \mathrm{mM}$ & 2 & 2.5 \\
\hline dNTPs & $2.5 \mathrm{mM}$ & 1 & 1 \\
\hline Forward primer & $30.0 \mathrm{ng} / \mu \mathrm{l}$ & 1.5 & 1 \\
\hline Reverse primer & $30.0 \mathrm{ng} / \mu \mathrm{l}$ & 1.5 & 1 \\
\hline Taq DNA polymerase & $5.0 \mathrm{units} / \mu \mathrm{l}$ & 0.2 & 0.5 \\
\hline Template DNA & - & 5 & 5 \\
\hline distilled water & - & 8.8 & 9 \\
\hline Total volume & & 20 & 20 \\
\hline
\end{tabular}

\section{Results and discussion}

The aim of this work was to assess the generic density of Meloidogyne females in the roots of tomatoes and to identify the Meloidogyne species present in these sites at a molecular level.

\subsection{Density of Meloidogyne females at the sites}

A total of 30 roots composite samples were collected in 16 tomato production basins spread over the 4 districts. In the Ngaoundere ${ }^{\mathrm{e}}$ district, 8 samples were collected in 4 different sites (Camp prison, Marza, Wakwa and Vina), while in Ngaoundere II ${ }^{\mathrm{e}}$ district, 4 samples were collected in 2 sites (Sabongari and Gadamabanga), 13 samples in the 
Ngaoundere III e district were taken from 7 sites (Bini, Dang, Gada Bini, Manwi, Mbidjoro, Darang and Malang) and finally, 5 samples in Nganha district were taken from 3 sites (Borongo, Berem and Mbanfoulbe). This distribution of sample collection was a function of the density of areas sown to tomato crops in the districts.

From this study, it appears that the genus Meloidogyne was identified in all 30 sampling sites and therefore the frequency of distribution of this genus is $100 \%$ (Table 3). Following the principle of Fortuner and Merny [16] according to which a genus of nematode is frequent in an area when it is present in at least $30 \%$ of the samples, the genus Meloidogyne is more frequent in the studied area with a frequency that is largely superior to the threshold described by these authors. This observed frequency (100\%) could be explained by the particular typology of Meloidogyne as it can be found in almost any type of environment. It is known as a very ubiquitous nematode [26, 27] and is cited as an important nematode on vegetable and root crops [28]. Several research studies have reported the presence of this genus as the most frequent and damaging. A study conducted in Egypt by Ibrahim and Handoo [29] identified the genus Meloidogyne associated with the cultivation of Lantana camara, Mentha piperita, Psidium guajava and Olea europaea with frequencies of $54 \%, 46 \%, 56 \%$ and $60 \%$ respectively higher than that described by Fortuner and Merny [16]. Adam et al. [30] in their work discover that the most frequently found genus of nematodes was Meloidogyne, which was present in over $57 \%$ and $47 \%$ of the samples in 2009 and 2011 respectively.

Furthermore, it appears from this study that the distribution in number of females Meloidogyne in roots varies from one site to the other (Table 3). According to the scale of Fortuner and Merny [16], a genus is considered abundant in roots when there are at least 20 individuals per gram of dry root. According to this scale, the highest density of females in the roots was obtained at the sites of Camp prison 1 and 2, Marza 1, Wakwa, Vina 1 and 3, Bini 1, Dang 1, Gada Bini 1 and 2, Manwi 1 and 2, Mbidjoro, Darang 1, Malang 1 and 2, and finally at the Berem 1 and Mbanfoulbe sites, with an average density of 21-50 females per gram of dry root, which is higher than that described by Fortuner and Merny [16]. On these sites where high densities of Meloidogyne were observed, the previous crops noted were host plants of Meloidogyne with the exception of Mbanfoulbe where the practice of fallow had preceded cultivation of tomatoes. A faunistic study by Toure et al. [31] in the peri-urban area of Bamako on different vegetable crops showed high densities of Meloidogyne in tomato roots, well above 20 nematodes per gram of root. This importance of the genus Meloidogyne has also been reported by other researchers such as Mokrini and Sbaghi [32]; Haougui et al. [33]. These authors report that vegetable crops in general are attacked by a large number of nematodes, but those of the genus Meloidogyne seem to be the main problem. In contrast, low nematode densities were noted at the sites of Marza 2, Vina 2, Sabongari 1 and 2, Gadamabanga 1 and 2, Bini 2, Dang 2, Darang 2, Borongo 1 and 2, and at the Berem 2 site with values ranging from 6 to 19 females per gram of dry root. In these low density Meloidogyne sites, previous crops were on the one hand host plants, non-host Meloidogyne plants and on the other hand the practice of fallow.

\subsection{Physico-chemical properties of the soil}

At the end of the soil analysis carried out, the data of which are shown in table 4, we observe that the size distribution of particles in the soils reveals a little variable particle size between the soils depending on their origin. This analysis shows that $93.33 \%$ of the soil at these sites has higher proportions of sand, very poor clay and average silt contents. According to the triangular diagram of the soil textural classes of Jamagne [34], the soils of these study sites are of the sandy and sandy-silty type, with the exception of two sites (Borongo 1 and 2) where one notes rather the higher silt content (58,5\%). The $\mathrm{pH}$ value varies between 4.0 and 6.7 characterizing acidic soils and the high organic matter contents (3.04 - $7.69 \%$ ) reflect soils riche in this element (According to Anonyme, [35]). The $\mathrm{C} / \mathrm{N}$ ratio is between 3 and 8. In addition, high contents of exchangeable bases (SBE) and cation exchange capacity (CEC) are noted (According to Anonyme, [35]). The SBE/CEC ratio corresponding to the soil saturation rate reveals that $63.33 \%$ of soils are saturated (> $60 \%), 26.67 \%$ are moderately saturated (41-60\%) and $10 \%$ of soil are weakly saturated (21-40 \%) according to the scale of Beernaert and Bitondo [36].

The principal component analysis carried out to visualize the possible correlations between the environmental variables and the density of Meloidogyne in tomato roots is shown in figure 2 below. As a result of this analysis, the principal components F1 and F2 explain 50.59\% of the variability. The density of Meloidogyne in the roots is correlated with some physical, chemical and biological variables. The parameters that would explain the abundance of Meloidogyne in the sample sites are respectively high proportion of sand, minimum moisture (64.8-74.8\%), cultural precedence of the host plants, acidic soil pH of the sample sites. These variables are positively correlated with each other. On the other hand, variables such as clay and silt content, soil organic matter content, saturation rate and finally fallow practice and cultural precedence of non-host plants would account for the low densities of Meloidogyne in some sites. 
Table 3 Density, tomatoes cultivators, cultivation practice and Meloidogyne species identified in the study sites

\begin{tabular}{|c|c|c|c|c|c|c|c|}
\hline Districts & Sites & Codes & $\begin{array}{l}\text { Tomato } \\
\text { cultivars }\end{array}$ & $\begin{array}{c}\text { Previous } \\
\text { crop }\end{array}$ & $\begin{array}{c}\text { Sampling } \\
\text { periods }\end{array}$ & $\begin{array}{c}\text { Female } \\
\text { density } \\
\text { (per gram of } \\
\text { dry root) }\end{array}$ & $\begin{array}{c}\text { Meloidogyne species } \\
\text { identified }\end{array}$ \\
\hline \multirow{8}{*}{$\begin{array}{c}\text { Ngaoundere } \\
\text { I }\end{array}$} & Camp prison 1 & Cp1 & Griffaton & ph & FSP & $32.00 \pm 3.00$ & M. incognita/M. hapla \\
\hline & Camp prison 2 & $\mathrm{Cp} 2$ & Griffaton & ph & DSP & $30.33 \pm 2.89$ & M. incognita/M. hapla \\
\hline & Marza 1 & Mz1 & Griffaton & $\mathrm{ph}$ & FSP & $31.67 \pm 2.52$ & M. incognita/M. hapla \\
\hline & Marza 2 & Mz2 & Griffaton & ja & FSP & $09.00 \pm 1.73$ & M. incognita/M. hapla \\
\hline & Wakwak & Wa & Griffaton & ph & FSP & $21.33 \pm 2.51$ & M. incognita/M. hapla \\
\hline & Vina 1 & Vi1 & Griffaton & $\mathrm{ph}$ & DSP & $22.67 \pm 2.51$ & M. incognita/M. hapla \\
\hline & Vina 2 & $\mathrm{Vi} 2$ & Olivette & $\mathrm{ph}$ & FSP & $16.00 \pm 2.64$ & M. incognita/M. hapla \\
\hline & Vina 3 & Vi3 & Griffaton & $\mathrm{ph}$ & FSP & $42.67 \pm 2.51$ & M. incognita/M. hapla \\
\hline \multirow{4}{*}{$\begin{array}{c}\text { Ngaoundere } \\
\text { II }\end{array}$} & Sabongari 1 & Sa1 & Griffaton & ph & DSP & $19.67 \pm 1.15$ & M. incognita/M. hapla \\
\hline & Sabongari 2 & $\mathrm{Sa} 2$ & Griffaton & pnh & FSP & $12.33 \pm 1.52$ & M. incognita/M. hapla \\
\hline & \begin{tabular}{|c|} 
Gaga mabanga \\
1
\end{tabular} & $\mathrm{Gm} 1$ & Griffaton & pnh & FSP & $12.00 \pm 1.73$ & M. incognita/M. hapla \\
\hline & $\begin{array}{c}\text { Gaga mabanga } \\
2\end{array}$ & $\mathrm{Gm} 2$ & Griffaton & ja & DSP & $10.00 \pm 1.73$ & M. incognita/M. hapla \\
\hline \multirow{13}{*}{$\begin{array}{c}\text { Ngaoundere } \\
\text { III }\end{array}$} & Bini 1 & Bi1 & Olivette & ph & FSP & $34.00 \pm 2.64$ & M. incognita/javanica \\
\hline & Bini 2 & $\mathrm{Bi} 2$ & Griffaton & ph & FSP & $16.67 \pm 1.15$ & M. incognita/javanica \\
\hline & Dang 1 & Da1 & Griffaton & ph & DSP & $35.33 \pm 4.01$ & M. incognita/javanica \\
\hline & Dang 2 & Da2 & Griffaton & ph & FSP & $16.00 \pm 3.00$ & M. incognita/M. hapla \\
\hline & Gada bini 1 & $\mathrm{~Gb} 1$ & Griffaton & $\mathrm{ph}$ & FSP & $50.33 \pm 9.71$ & M. incognita/M. hapla \\
\hline & Gada bini 2 & $\mathrm{~Gb} 2$ & Griffaton & ph & DSP & $25.67 \pm 2.89$ & M. incognita/M. hapla \\
\hline & Manwi 1 & Mw1 & Griffaton & $\mathrm{ph}$ & FSP & $42.67 \pm 2.52$ & M. incognita/javanica \\
\hline & Manwi 2 & Mw2 & Griffaton & $\mathrm{ph}$ & DSP & $40.67 \pm 4.04$ & M. incognita/javanica \\
\hline & Mbidjoro & $\mathrm{Mb}$ & Olivette & ph & FSP & $25.00 \pm 1.73$ & M. incognita/M. hapla \\
\hline & Darang 1 & Dr1 & Griffaton & ph & FSP & $23.00 \pm 1.00$ & M. incognita/javanica \\
\hline & Darang 2 & Dr2 & Griffaton & ja & DSP & $06.00 \pm 1.00$ & M. incognita/javanica \\
\hline & Malang 1 & Ma1 & Griffaton & ph & FSP & $35.33 \pm 5.68$ & M. incognita/javanica \\
\hline & Malang 2 & $\mathrm{Ma} 2$ & Griffaton & $\mathrm{ph}$ & FSP & $36.33 \pm 3.51$ & M. incognita/M. hapla \\
\hline \multirow{5}{*}{ Nganha } & Borongo 1 & Bo1 & Olivette & pnh & DSP & $16.00 \pm 3.00$ & M. incognita/javanica \\
\hline & Borongo 2 & Bo 2 & Griffaton & ja & FSP & $09.33 \pm 1.53$ & M. incognita/M. hapla \\
\hline & Berem 1 & $\mathrm{Be} 1$ & Olivette & ph & FSP & $35.33 \pm 2.89$ & M. incognita/M. hapla \\
\hline & Berem 2 & $\mathrm{Be} 2$ & Griffaton & ja & DSP & $09.00 \pm 2.65$ & M. incognita/javanica \\
\hline & MbanFoulbé & Mf & Griffaton & ja & FSP & $45.67 \pm 4.51$ & M. incognita/javanica \\
\hline
\end{tabular}


Nematodes of the genus Meloidogyne are generally present in several soil types, however, the highest levels of infestation and damage are most common in sandy soils [37,38]. These soil types seem to favour their movement. Prot [39] observed that the percentage of $M$. incognita juveniles able to migrate $20 \mathrm{~cm}$ and penetrate a tomato plant decreased when the percentage of fine particles (silts and clays) increased. No migration was noted when the soil contained more than $30 \%$ clays and silts. However, since sandy soil is very loose and loses water very quickly through infiltration, increased rainfall would correct the water deficit. This would improve the hatching of eggs embedded in the gelatinous mass, hence the increase in population, especially since this type of nematode develops more in sandy soils [40]. Clays make the soil very compact and thus limit the development of Meloidogyne spp. [38, 41]. Being poorly aerated, these types of soils are known to be asphyxiating to the nematode. Aeration has a direct effect on the hatching and activities of Meloidogyne juveniles in the soil. Oxygen deficiency reduces hatching and kills juveniles by asphyxiation. At low oxygen levels, the metabolism, movement and infesting power of juveniles are reduced [42]. Female growth and reproduction are also reduced [38]. Baxter and Blake [43] showed that all activities of $M$. javanica juveniles increase when the oxygen level increases from 0.2 to $21 \%$. With regard to soil pH as a factor that can directly influence the density of plant-parasitic nematodes, there is little data to support this. However, it appears from this study that Meloidogyne spp. are attracted to acidic pH. According to Jairjpuri and Azmi [44], nematodes in general are active in $\mathrm{pH}$ ranging from 5.8 to 8.

The correlation of the low density of Meloidogyne with the observed soil organic matter has been widely explained by several authors. Organic matter favours the development of natural antagonists of the nematode [45] and the products of its decomposition are toxic to the nematodes [46]. It also changes the physiology of the plant to become tolerant to the nematode [47]. This is consistent with the work of Norton [48] and Bongers and Ferris [49] according to which the addition of organic matter stimulates the activity of antagonistic organisms (predators and parasites) which become more abundant, provides resources for opportunistic nematodes and some organic acids (formic, acetic, propionic or butyric acid) resulting from the decomposition of this organic matter are toxic to nematodes. However, it was noted that the efficacy of organic matter depends on both the plant-parasitic species and the organic molecule available in the soil. For example, the work of Abawi and Widmer [50] and Oka [51] showed that the addition of lignins decreased the densities of Meloidogyne spp. in the roots and the addition of cellulose decreased the density of $R$. similis in the roots. Similarly, the positive correlation observed with soil saturation level, which informs about the availability of exchangeable bases, have adverse actions for nematodes. The nitrogen content of the soil is thought to be responsible for the plasmolysis of nematodes, but also for the proliferation of nematophagous fungi and chitinase-producing fungi that attack the eggshells of nematodes [52]. There is also a more indirect effect of easily degradable carbon (molasses or glucose) leading to a drop in the redox potential of the soil, which in turn leads to an increase in the activity of anaerobic bacteria that produce organic acids with nematicidal properties through fermentation [53].

Correlations were also noted between certain cultural practices and nematode density in the sites (figure 2). Indeed, the history of the plot influences the nematode population [28,54]. The crop precedent and the production systems in rotation with host plants of the Meloidogyne genus influence the density of the latter. In this study, there was a positive correlation between nematode density in the roots and the crop precedent of the host plants (Figure 2). These plants allow nematode survival in the absence of the main crop, thus favouring its establishment. Conversely, a non-host plant does not allow the multiplication of Meloidogyne, leading to a decrease in its population. A positive correlation was noted between the cultural precedent of the non-host plants and the low density of Meloidogyne observed. According to Sarr and Prot [55] a groundnut/fonio or groundnut/tomato rotation reduces the density and harmful action of Meloidogyne. Alternating aubergine with groundnut controls of $M$. incognita [56] and alternating cotton with groundnut gives a better control of M. arenaria [57]. Their mode of action is variable, they can act by inducing a decrease in egg production, inhibiting the growth of the pathogen or its development $[28,58]$. Fallowing also influences nematode density. It is also a way to decrease the rate of infestation of soils by plant-parasitic nematodes [59]. Similarly, a positive correlation between low nematode density and fallow practice can be seen in Figure 2 . The low densities of females in the roots observed at the sites of Darang 2, Borongo 2, Gadamabanga 2 and Marza 2 would be partly related to this practice. When food sources are no longer readily available, nematode population densities gradually decrease with death due to starvation. 
Table 4 Physico-chemical properties of soil at the study sites

\begin{tabular}{|c|c|c|c|c|c|c|c|c|c|c|c|c|}
\hline \multirow{2}{*}{ Districts } & \multirow{2}{*}{ Sites } & \multicolumn{3}{|c|}{ Granulometry (\%) } & \multirow{2}{*}{$\mathrm{pH}_{2} \mathrm{O}$} & \multirow{2}{*}{$\begin{array}{l}\text { M. org. } \\
\text { (\%) }\end{array}$} & \multirow{2}{*}{$\mathrm{C} / \mathrm{N}$} & \multirow{2}{*}{$\begin{array}{c}\text { P ass. } \\
\text { (mg/kg) }\end{array}$} & \multirow{2}{*}{$\begin{array}{c}\text { SBE } \\
\text { (meq/100g) }\end{array}$} & \multirow{2}{*}{$\begin{array}{c}\text { CEC } \\
\text { (meq/100g) }\end{array}$} & \multirow{2}{*}{$\begin{array}{c}\text { Saturation } \\
\text { (\%) }\end{array}$} & \multirow{2}{*}{$\begin{array}{c}\mathrm{Fe} \\
(\mathrm{mg} / \mathrm{kg})\end{array}$} \\
\hline & & Sand & Silt & Clay & & & & & & & & \\
\hline \multirow{8}{*}{ Ndere I } & Cp1 & 80.0 & 11.0 & 9.0 & 4.8 & 4.45 & 3 & 24.43 & 31.05 & 46.80 & 66.36 & 143.59 \\
\hline & $\mathrm{Cp} 2$ & 75.0 & 12.0 & 13.0 & 5.2 & 4.34 & 3 & 22.32 & 29.11 & 45.60 & 63.85 & 133.50 \\
\hline & Mz1 & 67.5 & 19.0 & 13.5 & 5.6 & 4.56 & 3 & 28.53 & 45.28 & 58.00 & 78.07 & 469.05 \\
\hline & $\mathrm{Mz2}$ & 56.5 & 27.5 & 16.0 & 6.2 & 5.57 & 3 & 38.53 & 46.38 & 60.00 & 77.30 & 458.00 \\
\hline & Wa & 76.0 & 16.0 & 8.0 & 4.6 & 4.02 & 3 & 22.03 & 35.01 & 49.20 & 71.15 & 93.79 \\
\hline & Vi1 & 68.0 & 24.0 & 8.0 & 5.1 & 5.32 & 4 & 45.44 & 29.82 & 51.00 & 58.47 & 346.60 \\
\hline & Vi2 & 59.0 & 31.0 & 10.0 & 5.4 & 6.32 & 4 & 44.44 & 30.82 & 50.00 & 61.64 & 356.60 \\
\hline & Vi3 & 65.0 & 26.0 & 9.0 & 4.6 & 5.72 & 4 & 43.44 & 33.82 & 52.00 & 65.04 & 286.60 \\
\hline \multirow{4}{*}{ Ndere II } & Sa1 & 47.0 & 37.0 & 16.0 & 5.8 & 5.93 & 2 & 125.28 & 44.56 & 55.00 & 81.02 & 112.48 \\
\hline & $\mathrm{Sa} 2$ & 45.0 & 38.0 & 16.0 & 5.4 & 5.93 & 3 & 125.28 & 48.56 & 60.00 & 80.93 & 122,48 \\
\hline & $\mathrm{Gm} 1$ & 56.0 & 36.5 & 7.5 & 4.5 & 4.67 & 4 & 27.33 & 23.42 & 29.50 & 79.40 & 85.55 \\
\hline & $\mathrm{Gm} 2$ & 47.0 & 46.0 & 7.0 & 4.3 & 6.67 & 4 & 27.33 & 21.42 & 28.50 & 75.16 & 75.55 \\
\hline
\end{tabular}


Table 5 Physico-chemical properties of soil at the study sites (end)

\begin{tabular}{|c|c|c|c|c|c|c|c|c|c|c|c|c|}
\hline \multirow{2}{*}{ Districts } & \multirow{2}{*}{ Sites } & \multicolumn{3}{|c|}{ Granulometry (\%) } & \multirow{2}{*}{ pHн2O } & \multirow{2}{*}{$\begin{array}{l}\text { M. org. } \\
\text { (\%) }\end{array}$} & \multirow{2}{*}{$\mathrm{C} / \mathrm{N}$} & \multirow{2}{*}{$\begin{array}{c}\text { P ass. } \\
\text { (mg/kg) }\end{array}$} & \multirow{2}{*}{$\begin{array}{c}\text { SBE } \\
\text { (meq/100g) }\end{array}$} & \multirow{2}{*}{$\begin{array}{c}\text { CEC } \\
\text { (meq/100g) }\end{array}$} & \multirow{2}{*}{$\begin{array}{c}\text { Saturation } \\
\text { (\%) }\end{array}$} & \multirow{2}{*}{$\begin{array}{c}\mathrm{Fe} \\
(\mathrm{mg} / \mathrm{kg}\end{array}$} \\
\hline & & Sand & Silt & Clay & & & & & & & & \\
\hline \multirow{13}{*}{ Ndere III } & Bi1 & 63.0 & 31.5 & 5.5 & 6.7 & 4.24 & 4 & 26.70 & 44.55 & 67.00 & 66.50 & 376.39 \\
\hline & $\mathrm{Bi} 2$ & 53.0 & 36.5 & 10.5 & 4.7 & 5.24 & 3 & 28.70 & 45.55 & 64.00 & 71.18 & 386.39 \\
\hline & Da1 & 79.0 & 15.0 & 6.0 & 5.2 & 3.04 & 3 & 29.81 & 34.03 & 70.00 & 48.61 & 101.16 \\
\hline & $\mathrm{Da} 2$ & 59.0 & 34.0 & 7.0 & 4.2 & 5.04 & 3 & 59.81 & 55.03 & 70.00 & 78.61 & 91.16 \\
\hline & $\mathrm{Gb} 1$ & 56.5 & 36.0 & 7.5 & 5.6 & 3.80 & 3 & 16.51 & 15.29 & 27.10 & 56.42 & 56.97 \\
\hline & $\mathrm{Gb} 2$ & 56.5 & 37.0 & 6.5 & 5.2 & 3.80 & 3 & 16.51 & 15.29 & 26.10 & 58.58 & 46.97 \\
\hline & Mw1 & 79.5 & 18.0 & 2.5 & 5.7 & 4.19 & 4 & 17.22 & 24.41 & 63.65 & 38.35 & 289.91 \\
\hline & Mw2 & 69.5 & 27.0 & 3.5 & 6.3 & 3.19 & 7 & 17.22 & 24.41 & 53.65 & 45.50 & 209.91 \\
\hline & $\mathrm{Mb}$ & 90.5 & 5.0 & 4.5 & 5.4 & 5.10 & 6 & 12.13 & 9.26 & 20.22 & 45.81 & 103.03 \\
\hline & Dr1 & 69.0 & 27.0 & 4.0 & 5.2 & 3.69 & 6 & 15.80 & 14.32 & 24.60 & 58.23 & 63.79 \\
\hline & Dr2 & 62.0 & 4.0 & 34.0 & 4.2 & 7.69 & 3 & 45.80 & 17.32 & 24.60 & 70.43 & 98.79 \\
\hline & Ma1 & 79.0 & 16.0 & 5.0 & 5.3 & 3.71 & 7 & 49.26 & 6.12 & 18.13 & 33.76 & 135.92 \\
\hline & Ma2 & 79.0 & 16.0 & 5.0 & 5.3 & 4.62 & 8 & 49.26 & 6.12 & 18.13 & 33.76 & 67.92 \\
\hline \multirow{5}{*}{ Nganha } & Bo1 & 31.5 & 58.5 & 10.0 & 4.1 & 7.45 & 7 & 23.87 & 36.83 & 50.20 & 73.37 & 184.56 \\
\hline & Bo2 & 31.5 & 58.5 & 10.0 & 4.0 & 6.65 & 5 & 23.87 & 35.83 & 56.20 & 63.75 & 104.56 \\
\hline & Be 1 & 72,0 & 23.0 & 5.0 & 5.5 & 3.41 & 7 & 29.03 & 15.02 & 25.85 & 58.11 & 82.25 \\
\hline & Be 2 & 69.0 & 25.0 & 6.0 & 4.4 & 6.21 & 8 & 39.03 & 25.02 & 30.55 & 81.90 & 202.24 \\
\hline & Mf & 71.0 & 23.5 & 5.5 & 5.8 & 6.73 & 8 & 15.95 & 20.32 & 31.28 & 64.96 & 56.86 \\
\hline
\end{tabular}




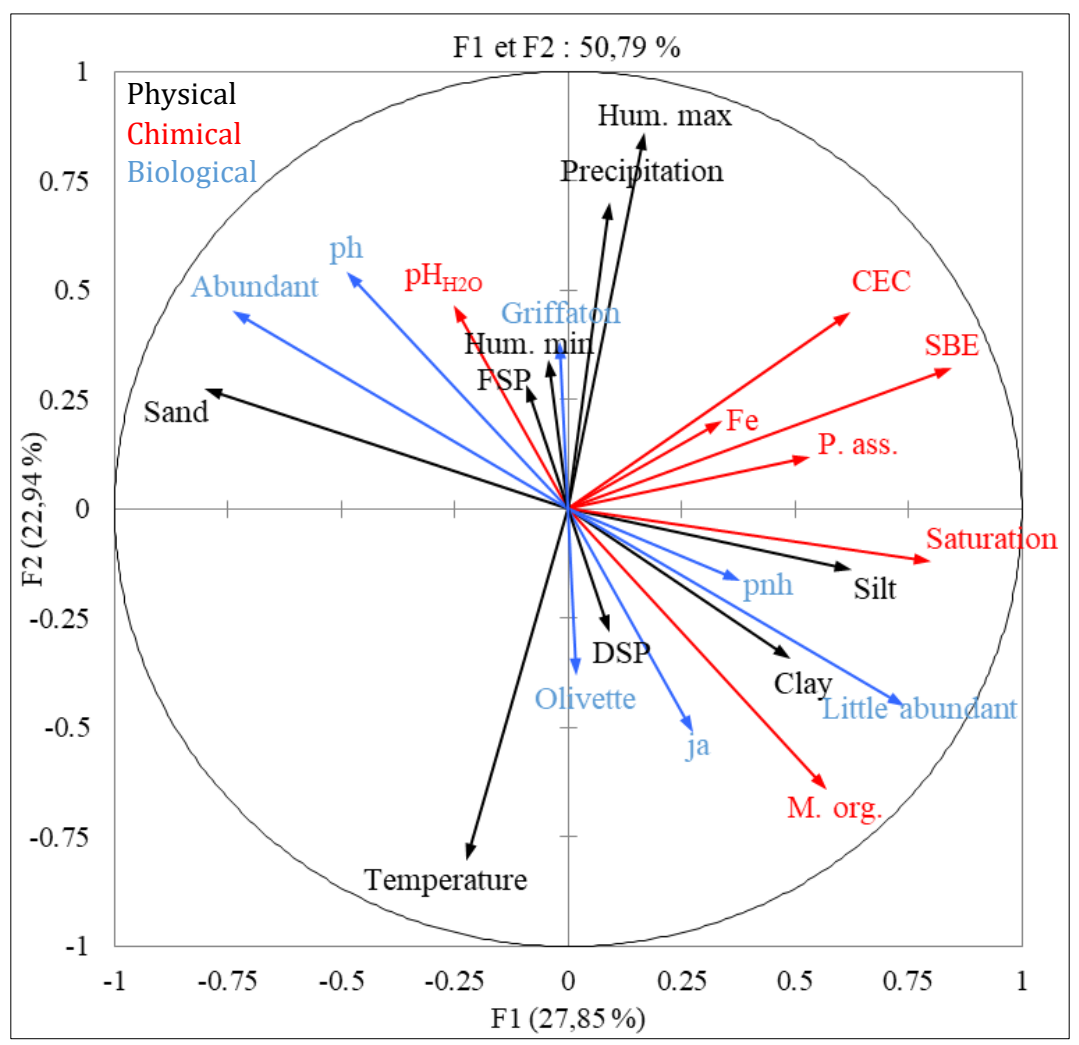

Figure 2 Correlation circle between physical, chemical and biological components. Hum. min: minimum humidity; Hum. max: maximum humidity

\subsection{Site-specific diversity of Meloidogyne}

The primers used in this study were able to amplify specific regions of Meloidogyne DNA isolated from the different sites. The electrophoretic profiles of the different amplified DNA samples are shown in Figure 3 below. Thus, the amplified PCR products submitted to electrophoresis migrated up to 1700 bp (figure $3 \mathrm{a}, \mathrm{b}$ ), $1100 \mathrm{bp}$ (figure $3 \mathrm{~b}$ ) and 421 bp (figure $3 \mathrm{c}, \mathrm{d}$, e) characteristic of the respective presence of M. incognita/M. javanica, M. arenaria and M. incognita/M. hapla in the sites (table 3). Indeed, the climatic (temperature, precipitation, humidity), pedological parameters as well as the different cultivation practices are favourable to the development of these species and consequently, could justify their presence in this area. These species are widely distributed in the world and are considered among the most damaging species on crops in general and tomatoes in particular. A recent study by Khanal et al. [60] in Arkansas, USA on 106 soil and root samples identified the presence of M. incognita, M. marylandi, M. haplanaria, M. hapla, M. arenaria and M. partityla Kleynhans, 1986 of which M. incognita was the most abundant species. Similarly, the work of Ye et al. [61] carried out in 39 countries on different plants (soybean, cotton, corn and various vegetables) identified the presence of these species in samples with a higher prevalence of M. incognita ( $95 \%$ ). This is also similar to studies conducted by Milad et al. [62] in South Africa which identified the presence of 4 species including M. enterolobii, M. javanica, M. incognita, and M. hapla. 


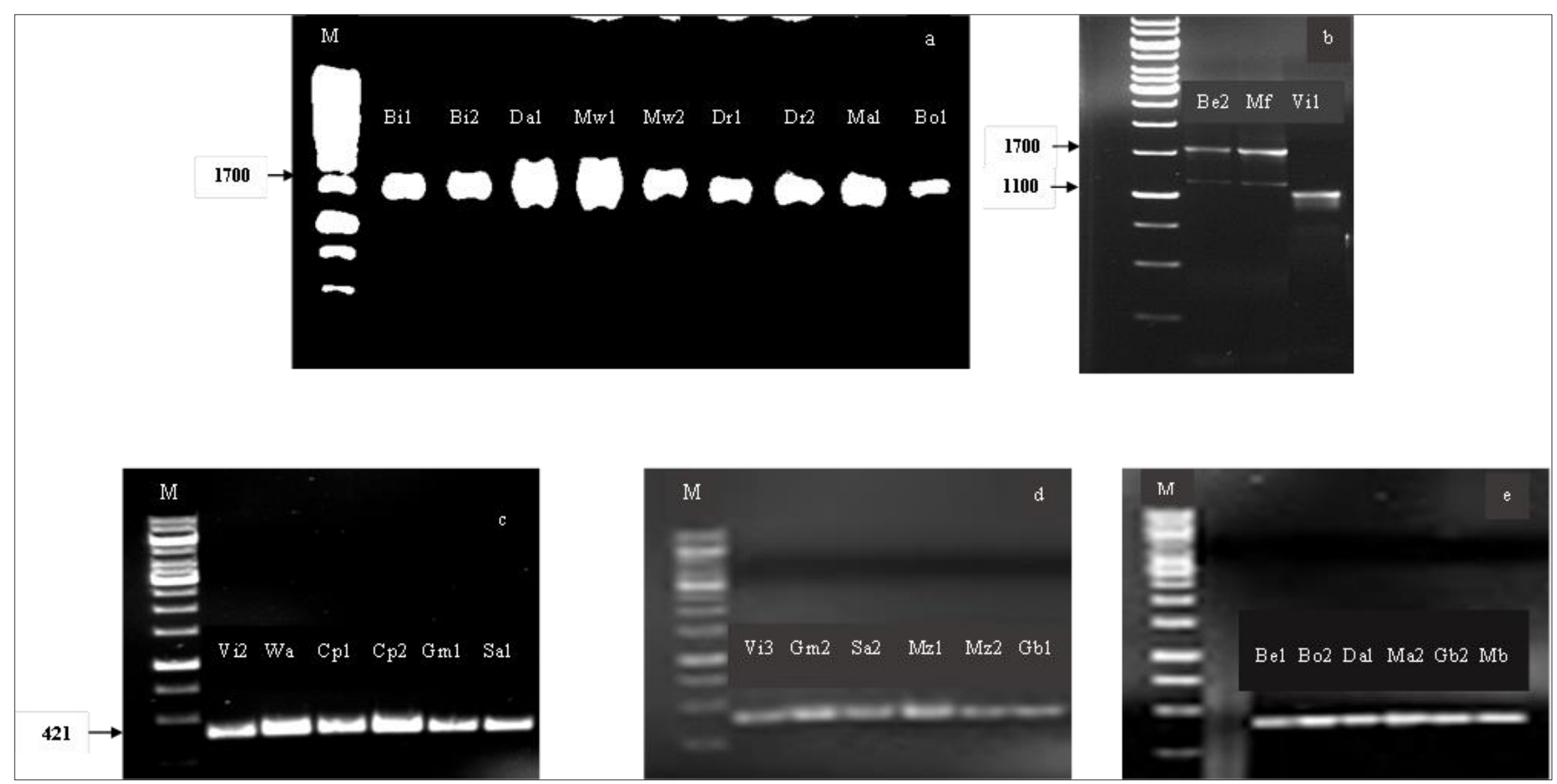

Figure 3 Electrophoretic profile of DNA amplicons from samples from different sites. 1700 bp characterizes the presence of M. incognita and M. javanica species (a, b), $1100 \mathrm{bp}$ characterizes the presence of M. arenaria species (b) and $421 \mathrm{bp}$ characterizes the presence of M. incognita and M. hapla species (c, d, e) 


\section{Conclusion}

The present work focused on the distribution and molecular identification of nematodes of the genus Meloidogyne in the Cameroonian Guinean high savannah agro-ecological zone. The study showed that the genus Meloidogyne is more frequent in this zone with high densities in some sites ranging from 21 to 50 females per gram of fresh root and low densities ranging from 6 to 19 females per gram of root. However, the high densities observed are due to the high sand content of the soil, the $\mathrm{pH}$ value and minimum moisture and the cultural precedents of the host plants. On the other hand, the silt and clay content, the organic matter content of the soil, the saturation rate and also certain cultural practices such as fallowing and the pre-cultivation of non-host plants lead to a decrease in pest density. In terms of molecular identification, species such as $M$. incognita/M. javanica, M. arenaria and M. incognita/M. hapla were identified. The results of this work constitute an important tool that can assist an organized agricultural profession in the choice and development of effective control programmes against the main Meloidogyne species, which constitutes an alternative strategy for the development of sustainable local production based on the reduction of nematodes on the farm.

\section{Compliance with ethical standards}

\section{Acknowledgments}

We would like to thank the Alexander von Humboldt Foundation (AvH) for their material support.

\section{Disclosure of conflict of interest}

The authors declare that they have no competing interests. There is no conflict of interest regarding the publication of this article.

\section{References}

[1] Blok VC, Jones JT, Phillips MS, Trudgill DL. Parasitism genes and host range disparities in biotrophic nematodes: the conundrum of polyphagy versus specialization. BioEssays: news and reviews in Molecular, Cellular and Developmental Biology. 2008; 30(3): 249-59.

[2] IITA. Proceedings of the third research planning conference on root-knot nematodes, Meloidogyne spp. International Meloidogyne Project. 1981; 1-286.

[3] FAO. The state of food security in the world: Economic Crises - Impacts and Lessons Learned. Electronic Publishing Policy and Support Branch : Communication Division; 2009.

[4] Rajeswari M, Ramakrishnan S. Influence of Streptomyces fradiae against root knot nematode Meloidogyne incognita in tomato. Research Journal of Agriculture and Forestry Sciences. 2015; 3(1): 6-11.

[5] Koenning SR, Overstreet C, Noling JW, Donald PA, Becker J0, Fortnum BA. Survey of crop losses in response to phytoparasitic nematodes in the United States for 1994. Nematol. 1999; 31(4): 587-618.

[6] Netscher C, Mauboussin JC. Résultat d'un essai concernant l'efficacité comparée d'une variété résistante et de certains nématicides contre Meloidogyne javanica. Série Biologie. 1973; 21: 97-102.

[7] Chaux C, Foury CL. Les productions légumières. Tome 3 : Légumineuses potagères - Légumes fruits. Coll. « AGRICULTURE D'AUJOURD'HUI : Sciences, Techniques, Applications ». Lavoisier, Paris, France : Tec \& Doc ; 1994.

[8] FAO. Données de la base statistique de l'organisation des Nations Unies pour l'Alimentation et l'Agriculture sur le site. Rome; 2008.

[9] PROTA. Vegetables/Légumes, Affichage de fiche. Institut de Recherche Agronomique; 2008.

[10] MINADER (Ministère de l'Agriculture et du Développement Rural). Annuaire des Statistiques du Secteur Agricole du Cameroun. Direction des Enquêtes et des Statistiques Agricoles. Agri-stat; 2012.

[11] Fontem DA. Quantitative effects of early and late blights on tomato yields in Cameroon. Tropicultura. 1993; 21(1): 36-41.

[12] Sikora RA, Fernandez E. Nematodes parasites of vegetables. In: PlantParasitic Nematodes in Subtropical and Tropical Agriculture (2nd eds). CABI Publishing, Wallingford. 2005; 1230: 319-392. 
[13] IRAD (Institut de la Recherché Agricole pour le Développement). Deuxième rapport sur l'état des ressources phytogénétiques pour l'alimentation et l'agriculture au Cameroun. 2014; 22.

[14] Tchuenguem FFN, Mapongmetsem PM, Hentchoya Hemo J, Messi J. Exploitation des fleurs de quatre plantes oléagineuses par Apis mellifera à Ngaoundéré (Cameroun): Bombax pentandrum, Vitellaria paradoxa, Lophira lanceolata et Dacryodes edulis. Procèdes Biologiques et Alimentaires. 2004 ; 2(1): 27-36.

[15] Tessier R. Méthode officielle d'analyse: extraction, détection et identification morpho biométriques des nématodes phytoparasites. Direction générale de l'alimentation et de la pêche. MOA012 version 1a. 2010.

[16] Fortuner R, Merny G. Les nématodes parasites des racines associés au riz en Basse Casamance (Sénégal) et en Gambie. Cah. ORSTOM, Sér. Biol. 1973; 21: 3-20.

[17] NF X31-107. Qualité du sol-Détermination de la distribution granulométrique des particules du sol - Méthode à la pipette. AFNOR, Paris. 2003; 20.

[18] ISO 13878. Soil quality - Determination of total nitrogen content by dry combustion (elemental analysis). AFNOR Paris; 1998.

[19] ISO 10694. Soil quality - Determination of organic and total carbon after dry combustion (elementary analysis). AFNOR Paris; 1995.

[20] ISO 11263. Soil quality - Determination of phosphorus - Spectrometric determination of phosphorus soluble in sodium hydrogen carbonate solution. AFNOR Paris; 1995.

[21] ISO 14869-1. Soil quality - Dissolution for the determination of total element content - Part 1: Dissolution with hydrofluoric and perchloric acids. AFNOR Paris; 2001.

[22] ISO 10390. Soil quality - Determination of pH. AFNOR Paris; 2005.

[23] ISO 11265. Soil quality - Determination of the specific electrical conductivity. AFNOR Paris; 1995.

[24] Powers TO, Harris TS. A polymerase chain reaction method for identification of five major Meloidogyne species. J. Nematol. 1993; 25: 1-6.

[25] Lazarova SS, Malloch G, Oliveira MG, Hübschen J, Neilson R. Ribosomal and Mitochondrial DNA Analyses of Xiphinema americanum group Populations. Journal of Nematology. 2006; 38(4): 404-410.

[26] Gnonhouri PG, Adiko A. Aperçu sur les nématodes phytoparasites. Bioterre, Rev. Inter. Sci. de la Vie et de la Terre. 2005; 5(1): 34-43.

[27] Nandjui J, Gnonhouri GP, Tondoh EJ, Tano Y. Réponse des nématodes à la perturbation des forêts dans la région d'Oumé, Côte d'Ivoire. Sciences \& Nature. 2007; 4(2): 189-196.

[28] Coyne DL, Nicol JM, Claudius-Cole B. Les nématodes des plantes : Un guide pratique des techniques de terrain et de laboratoire. Secrétariat SP-IPM, Institut International d'Agriculture Tropicale (IITA), Cotonou, Benin. 2010.

[29] Ibrahim IKA, Handoo ZA. Occurrence of phytoparasitic nematodes on some crop plants in northern Egypt. Pakistan Journal of Nematology. 2016; 34(2): 163-169.

[30] Adam M, Heuer H, Ramadan EM, Hussein MA, Hallmann J. Occurrence of plant-parasitic nematodes in organic farming in Egypt. International Journal of Nematology. 2013; 23: 82-90.

[31] Touré, Boubacar K, Sako S, Haougui A, Maïga M. Diversité des communautés des nématodes parasites associées aux cultures maraîchères dans la zone périurbaine de Bamako (Mali). Global Scientific Journals. 2019; 7(6): 916924.

[32] Mokrini, Sbaghi M. Les nématodes à galles, un programme intégré de lutte est nécessaire. Agriculture du Maghreb. 2017; 104: 3.

[33] Haougui A, Basso MI, Mossi. Les nématodes parasites du Moringa dans la zone périurbaine de Niamey. Institut National de la Recherche Agronomique du Niger. 2017; 1-10.

[34] Jamagne M. Bases et techniques d'une cartographie des sols. In Annales agronomiques. Paris: INRA. 1967; 18: 142.

[35] Anonyme. Plantes légumières. In : Mémento de l'Agronome. Ministère de la Coopération et du Développement, République Française. 4ème édition. Collection « Techniques rurales en Afrique »; 1991. 
[36] Beernaert F, Bitondo D. Simple and practical methods to evaluate analytical data of soil profiles. Dschang: CUDs, Soil Science Department Belgian cooperation; 1992.

[37] Pittcher RS. Facteurs influençant le mouvement des nématodes dans le sol. In: Lamberti, F., Taylor, C. E. \& Seinhorst, J.W. Nematodes vectors of plant viruses. Nato Advanced Study Institutes Series, Sér. A: Lijè Sciences. 1979; 2: 289-408.

[38] Van Gundy SD. Ecology of Meloidogyne spp.: emphasis on environment factors affecting survival and pathogenicity. Uz: Barker KR, Carter CC, Sasser JN. An advanced treatise on Meloidogyne. Biology and Control. IMP, North Carolina State Univresity Graphies, USA. 1985; 1: 177- 182.

[39] Prot JC. Recherches concernant le déplacement des juvéniles de Meloidogyne spp. vers les racines. Cah. ORSTOM, Sér. Biol. 1975 ; 10: 251-253.

[40] Netscher C. Les nématodes parasites des cultures maraîchères au Sénégal. Cah. ORSTOM, Sér. Biol. 1970; 11: 209229.

[41] Kincaid RR. Soil factors affecting incidence of root knot. Soil Science. 1946; 61: 101-109.

[42] De Guiran G, Netscher C. Les nématodes du genre Meloidogyne parasites de cultures maraîchères au Sénégal. Cah. ORSTOM, Sér. Biol. 1970; 11: 151-158.

[43] Baxter RI, Blake CD. Some effects of suction on the hatching eggs of Meloidogyne javanica. Ann. appl. Biol. 1969; 63: 183-190.

[44] Jairajpuri MS, Azmi MI. Aggregation and repulsion of nematodes at pH gradients. Nematol. Medit. 1978; 6: 107-1 12.

[45] Mankau R, Minteer RJ. Reduction of soil populations of the citrus nematode by the addition of organic materials. Plant Disease Reptr. 1962; 46: 375-8.

[46] Sayre RM, Patrick ZA, Thorpe HJ. Identification of selective nematicidal component in extracts of plant residues decomposing in soil. Nematological. 1965; 11: 263-268.

[47] Van der Laan PA. The influence of organic maturing on the development of Verschoor B.C: 2002. Carbon and nitrogen budgets of plant-feeding nematodes in grasslands of different productivity. Applied Soil Ecology. 1956; 20: 15- 25 .

[48] Norton DC. Relationship of physical and chemical factors to populations of plant parasitic nematodes. Annual Review of Phytopatology. 1979; 17: 279-299.

[49] Bongers T, Ferris H. Nematode community structure as a bioindicator in environmental monitoring. Trends in Ecology and Evolution. 1999; 14: 224-228.

[50] Abawi GS, Widmer TL. Impact of soil health management practices on soilborne pathogens, nematodes and root diseases of vegetable crops. Applied Soil Ecology. 2000; 15: 37-47.

[51] Oka Y. Mechanisms of nematode suppression by organic soil amendments - A review. Applied Soil Ecology. 2010; 44: 101-115.

[52] Rodriguez-Kabana R. Organic and inorganic nitrogen amendments to soil as nematode suppressants. J. Nematol. 1986; 18: 129-35.

[53] Browning M, Dawson C, Alm SR, McElderry CF, Amador J. Effect of carbon amendment and soil moisture on Tylenchorhynchus spp. and Hoplolaimus galeatus. Journal of Nematology. 1999; 31: 445-454.

[54] Bélair G. Les nématodes, ces anguillules qui font suer les plantes par la racine. Phytoprotection. 2005; 86(1): 6569.

[55] Sarr E, Prot JC. Pénétration et développement des juvéniles d'une souche de Meloidogyne javanica et d'une race B de M. incognita dans les racines de fonio (Digitaria exilis). Revue de Nématolorrie. 1986; 8(1): 59-65.

[56] Netscher C. Control of Meloidogyne in vegetable production by crop rotation in the Ivory Coast. Acta Horticultura. 1983; 152: 219-225.

[57] Rodriguez-Kabana R, Vev RH, Backman PA. Peanut-cotton rotation for the management of Meloidogyne arenaria. Journal of Nematologv. 1987; 19: 484-486. 
[58] Wang KH, Sipes BS, Schmitt DP. Crotalaria as a cover crop for nematode management: A review. Nematropica. 2002; 32: 35-57.

[59] Sawadogo A, Thio B, Konaté YA, Cadet P. Influence du temps de jachère sur les peuplements de nématodes phytoparasites dans un terroir de Bondoukuy à l'Ouest du Burkina Faso. Agronomie Africane. 2002; 14(2): 117125.

[60] Khanal C, Robbins RT, Faske TR, Szalanski AL, McGawley EC, Overstreet C. Identification and haplotype designation of Meloidogyne spp. of Arkansas using molecular diagnostics. Nematropica. 2016; 46: 261-270.

[61] Ye W, Robbins RT, Kirkpatrick T. Molecular characterization of root knot nematodes (Meloidogyne spp.) from Arkansas, USA. Scientific Reports. 2019; 9: 15680.

[62] Milad R, Marais M, Mieke SD, Mienie MS, Hendrika F. Molecular characterization of Meloidogyne enterolobii and other Meloidogyne spp. from South Africa. Tropical Plant Pathology. 2019; 44: 213-224. 